\title{
1 High-strength ammonium wastewater treatment by \\ 2 MBR: Steady-state nitrification kinetic parameters
}

\section{Authors:}

4 Dany Roy ${ }^{a}$, Sanae Benkaraache ${ }^{a}$, Jean-François Lemay ${ }^{b}$, Dany Landry, Patrick

5 Drogui ${ }^{a,{ }^{*}}$, Rajeshwar D. Tyagi ${ }^{a}$

6 a INRS, 490, rue de la Couronne, Québec, Qc., Canada, G1K 9A9

$7 \quad$ b CNETE, 5230, Boul. Royal, Shawinigan, Qc, Canada, G9N 4R6

$8 \quad$ c Englobe Corp., 505 Boul. de Parc Technologique, Québec, Qc., Canada, G1P 4S7

$9 \quad$ * patrick.drogui@ete.inrs.ca

\section{Abstract:}

12 In this study, a steady-state operation approach is proposed in order to accurately

13 measure the kinetic parameters of substrate (contaminants) removal in wastewater

14 biotreatment systems. In order to determine the kinetic parameters of a submerged

15 membrane bioreactor (SMBR) when treating high-strength ammoniacal nitrogen

16 wastewaters, a lab-scale SMBR was operated for 205 days with synthetic leachates

$17\left(1000 \mathrm{mg} \mathrm{COD} \mathrm{L}^{-1}\right)$ at 4 different ammoniacal nitrogen concentrations $(220,340,665$

18 and $1040 \mathrm{mg} \mathrm{NH} \mathrm{NH} \mathrm{L}_{4}^{-1}$ ). Ammoniacal nitrogen oxidation rates were calculated by

19 solving the mass balance equations when steady-state conditions were reached for each

20 tested concentration. The Haldane model was found to be accurate when predicting the

21 specific ammoniacal nitrogen oxidation rates with the following kinetic parameters: $\mathrm{r}_{\mathrm{NH}, \max }$ $22=854,4 \mathrm{mg} \mathrm{NH}_{4}-\mathrm{N} \mathrm{L}^{-1} \mathrm{~d}^{-1}, \mathrm{~K}_{\mathrm{S}}=1007 \mathrm{mg} \mathrm{NH}_{4}-\mathrm{N} \mathrm{L}^{-1}$, and $\mathrm{K}_{\mathrm{I}}=221 \mathrm{mg} \mathrm{NH} \mathrm{NL} \mathrm{L}^{-1}\left(\mathrm{R}^{2}=\right.$ 23 0,97). The highest ammoniacal nitrogen oxidation rate was found to be $162 \mathrm{mg} \mathrm{NH}_{4}-\mathrm{N} \mathrm{L}^{-}$ 
$24{ }^{1} \mathrm{~d}^{-1}$ when the effluent concentration was $472 \mathrm{mg} \mathrm{NH} \mathrm{NH} \mathrm{L}^{-1}$. When compared to the 25 conventional flask test approach for calculating the kinetic parameters, the steady-state 26 approach described in this study showed a lower variability in the predicted specific 27 nitrification rates, as well as a lower effect of the inhibition phenomena, due to the mixed 28 liquor being adapted to each substrate concentration tested.

29 Keywords: kinetic, membrane bioreactor, ammoniacal nitrogen, leachate, nitrification

30 Declarations of interest: none

31 
$32 \quad$ Abbreviations

33

$34 \quad \mathrm{AOB}$

Ammonia oxidizing bacteria

$35 \quad \mathrm{BOD}_{5}$

Biological oxygen demand (5 days)

$36 \quad$ CAS

Conventional activated sludge

37

COD

Chemical oxygen demand

$38 \quad$ CSTR

Continuous stirred tank reactor

$39 \quad$ DO

Dissolved oxygen

$40 \quad F: M$

Food: microorganism (biomass) ratio

$41 \quad$ HRT

Hydraulic retention time

$42 \quad$ SRT

Solid retention time

$43 \quad$ MBBR

Mixed bed bioreactor

$44 \quad$ MBR

Membrane bioreactor

$45 \quad$ MLVSS

Mixed liquor volatile suspended solids

$46 \quad$ NLR

Nitrogen load rate

$47 \quad$ qPCR

quantitative polymerase chain reaction

$48 \quad$ SBR

Sequencing batch reactor

$49 \quad$ SMBR

Sumberged membrane bioreactor

$50 \quad$ TMP

Transmembrane pressure

51

52 


\section{1. Introduction}

54 High-strength ammonium wastewater originating from anthropogenic activity, such as 55 aquaculture water (Ling and Chen 2005), composting leachates (Roy, Azaïs et al. 2018), 56 and landfill leachates (Ahmed and Lan 2012, Zolfaghari, Drogui et al. 2017), poses a 57 serious threat to the preservation of clean water resources. Reported ammoniacal 58 nitrogen concentrations measured in composting and landfill leachates range from $5 \mathrm{mg}$ $59 \mathrm{NH}_{4}-\mathrm{N} \mathrm{L}^{-1}$ to more than $21000 \mathrm{mg} \mathrm{NH}_{4}-\mathrm{N} \mathrm{L}^{-1}$ (Roy, Azaïs et al. 2018). Once discharged 60 in the aquatic environment, ammoniacal nitrogen can have adverse effects such as 61 promoting eutrophication, toxicity to aquatic organisms, and depletion of dissolved 62 oxygen due to the oxidation of ammoniacal nitrogen to nitrate (He, Xue et al. 2009).

63 High-strength ammoniacal nitrogen wastewater treatment has become a major focus in 64 recent years due to its negative impact on municipal wastewater biological treatment 65 systems. Even with the co-treatment of high-strength ammoniacal nitrogen wastewater 66 with municipal wastewater, the dilution factor is often insufficient to fade the 67 concentration peaks that have inhibitory effects on the microbial activity in the mixed 68 liquor (Gagnaire, Wang et al. 2011). Consequently, treatment systems have been 69 specifically engineered to treat wastewaters with high ammoniacal nitrogen 70 concentrations. Amongst these treatment systems, physico-chemical systems, such as 71 stripping, are frequently used (Carrera, Jubany et al. 2004). However, recent

72 developments in biological treatment systems have broadened their range of

73 applications and increased their efficacy with complex wastewaters. A biotechnology that 74 has been proven to be efficient for the removal of high concentrations of ammoniacal 75 nitrogen, even in the presence of a high chemical oxygen demand (COD), is the 76 membrane bioreactor (MBR). 
77 MBRs are distinguished from conventional activated sludge systems (CAS) by the use of

78 a micro/ultrafiltration membrane to separate the biomass from the effluent $(\mathrm{Ng}$ and $\mathrm{Kim}$

79 2007). The membrane eliminates the need for large clarifying basins to settle the

80 biomass, which consequently enables the system to be more compact. Furthermore, the

81 membrane provides an independent control of the hydraulic retention time (HRT) and

82 the solid retention time (SRT). Therefore, biomass can be kept in the system regardless

83 of its ability to settle. The biomass in MBRs is composed of a complex community of

84 microorganisms using different energy sources. Autotrophic nitrifying bacteria convert

85 ammoniacal nitrogen to nitrates in order to obtain their energy, while heterotrophic

86 microorganisms transform organic molecules to $\mathrm{CO}_{2}$. When wastewater contains both

87 ammoniacal nitrogen and organic contaminants (COD), both types of microorganisms

88 are desired in the mixed liquor. However, due to their slow growth rate, autotrophic

89 nitrifying bacteria are often outcompeted for nutrients and oxygen by heterotrophic

90 bacteria in CAS. Under the conditions created by the membrane in the MBRs, slow-

91 growing nitrifying bacteria can proliferate and survive in a population dominated by

92 heterotrophic bacteria.(Canziani, Emondi et al. 2006). Ammoniacal nitrogen removal

93 rates from leachates using different configurations of MBRs were reported to range from

9480 to $\sim 100 \%$, while initial concentrations ranged from 200 to $2800 \mathrm{mg} \mathrm{NH}_{4}-\mathrm{N} \mathrm{L}^{-1}$ (Ahmed

95 and Lan 2012). Although there has been significant research on membrane bioreactor

96 systems for the treatment of leachates with high COD and ammoniacal nitrogen

97 concentrations, there remains a lack of information relative to MBR bioprocesses

98 kinetics (Laitinen, Luonsi et al. 2006, Brown, Ghoshdastidar et al. 2013, Hashemi 2015,

99 Hashemi, Hajizadeh et al. 2016, Zuriaga-Agustí, Mendoza-Roca et al. 2016).

100 Nitrification kinetics in conventional biological treatment processes such as CAS, moving 101 bed bioreactor (MBBR), and sequential batch reactor (SBR), have been previously 
102 studied. Wastewater's characteristics and kinetic parameters from these studies are

103 presented in Table 1. In general, the nitrification kinetic in bioreactors is modeled

104 according to 1 of the 3 following models: 1) $0^{\text {th }}$ order kinetic, 2) Michaelis-Menten

105 (Monod), and 3) Haldane (Carrera, Jubany et al. 2004, Kaczorek and Ledakowicz 2006).

106 With the $0^{\text {th }}$ order kinetic model (Eq. 1), the ammoniacal nitrogen consumption rate is

107 assumed constant, notwithstanding the ammoniacal nitrogen concentration in the

108 effluent (He, Xue et al. 2009). The Michaelis-Menten model (Eq. 2) assumes an

109 increasing consumption rate until a maximum rate is reached (Dinçer and Kargı 2000,

110 Carrera, Jubany et al. 2004, Kaczorek and Ledakowicz 2006, Whang, Chien et al. 2009,

111 Gagnaire, Wang et al. 2011). The Haldane model (Eq. 3) integrates an inhibition term in

112 the Michaelis-Menten model to take into account the inhibitive effect of the substrate at

113 high concentrations.

$$
r_{N H, i}=k_{N H}
$$

$$
r_{N H, i}=r_{N H, \max } \frac{N_{N H}}{K_{S}+N_{N H}}
$$

$$
r_{N H, i}=r_{N H, \max } \frac{N_{N H}}{K_{S}+N_{N H^{+}}{ }^{2}{ }_{N H}^{2} / K_{I}}
$$

\section{With:}

$118 \mathrm{r}_{\mathrm{NH}, \mathrm{i}}=$ Ammoniacal nitrogen consumption rate at "i" concentration $\left(\mathrm{mg} \mathrm{NH}_{4}-\mathrm{N} \mathrm{L}^{-1} \mathrm{~d}^{-1}\right)$

$119 \mathrm{r}_{\mathrm{NH}, \max }=$ Maximum ammoniacal nitrogen consumption rate $\left(\mathrm{mg} \mathrm{NH}_{4}-\mathrm{N} \mathrm{L}^{-1} \mathrm{~d}^{-1}\right)$

$120 \mathrm{k}_{\mathrm{NH}}=$ Consumption rate constant $\left(\mathrm{mg} \mathrm{NH}_{4}-\mathrm{N} \mathrm{L}^{-1} \mathrm{~d}^{-1}\right)$

$121 \mathrm{~N}_{\mathrm{NH}}=$ Ammoniacal nitrogen concentration in the reactor $\left(\mathrm{mg} \mathrm{NH}_{4}-\mathrm{N} \mathrm{L}^{-1}\right)$ 
$122 \mathrm{Ks}=$ Saturation coefficient $\left(\mathrm{mg} \mathrm{NH}_{4}-\mathrm{N} \mathrm{L}^{-1}\right)$

$123 \mathrm{~K}_{\mathrm{I}}=$ Inhibition coefficient $\left(\mathrm{mg} \mathrm{NH}_{4}-\mathrm{N} \mathrm{L}^{-1}\right)$

124 Doyle et al. (2001) reported an exceptionally high nitrification rate ( $0^{\text {th }}$ order) in a SBR 125 that treats landfill leachate. However, in order to report a $0^{\text {th }}$ order kinetic consumption 126 rate, they neglected the non-linear section of their consumption curve at low 127 concentrations, which led to a highly overestimated consumption rate. Generally, $0^{\text {th }}$ 128 order kinetics are good estimations for small ranges of concentrations only (Doyle, Watts 129 et al. 2001), while the Michaelis-Menten and Haldane models are more representative of 130 biological kinetics over wider ranges.

131 The conventional experimental methods used to measure the ammoniacal nitrogen 132 consumption rate and the kinetics parameters $\left(\mathrm{r}_{\mathrm{NH}, \max }, \mathrm{K}_{\mathrm{S}}\right.$ and $\left.\mathrm{K}_{\mathrm{i}}\right)$ is the flask test (batch 133 method). It consists of preparing flasks with different initial ammoniacal nitrogen 134 concentrations and adding the same amount of sludge taken from the mixed liquor of the 135 studied treatment system into each of them. Then, changes in ammoniacal nitrogen 136 concentration are measured over a specific period of time. The measured consumption 137 rates $\left(r_{N H, i}\right)$ are expressed in $\mathrm{mg} \mathrm{NH}_{4}-\mathrm{N} \mathrm{L}^{-1} \mathrm{~d}^{-1}$ or in $\mathrm{mg} \mathrm{NH}_{4}-\mathrm{N} \mathrm{gMLVSS}^{-1} \mathrm{~d}^{-1}$ (mixed liquor 138 volatile suspended solids). While this technique is accurate for the measurement of cell 139 growth and enzyme activity, it has significant limitations in terms of substrate removal 140 kinetics measurements in wastewater treatment systems. Firstly, batch experiments tend 141 to overestimate the inhibitive effect of secondary metabolites and products generated by 142 microorganisms, since they accumulate in the bulk. Then, the F:M ratio in the flask is not 143 representative of that of the reactor from which the mixed liquor was taken. For example, 144 Whang et al. (2009) conducted a flask test to measure the nitrification kinetic in a SBR 145 that treated swine wastewater. Their method consisted in taking mixed liquor from the 
146 reactor and suspending it in $1 \mathrm{~L}$ of Bushnëll et Haas medium with ammoniacal nitrogen

147 concentrations ranging from 1 to $600 \mathrm{mg} \mathrm{NH}_{4}-\mathrm{N} \mathrm{L}-1$, while the SBR from which the

148 mixed liquor originated was operated with concentrations of $215 \pm 12 \mathrm{mg} \mathrm{NH}-\mathrm{N} \mathrm{L-1}$

149 (Whang, Chien et al. 2009). This method wrongly assumes that the F:M ratio

150 ([NH $\left.\mathrm{NH}_{4}\right]$ :ammonia oxidizing bacteria (AOB) concentration) has no influence on the

151 consumption rate measured in the flask. The consequence of this assumption is that

152 there is an excess of $A O B$ at low ammoniacal nitrogen concentrations in the flask (in

153 comparison to the concentration of the treated effluent) $\left([\mathrm{F}: M]_{\text {flask }}<[\mathrm{F}: M]_{\text {reactor }}\right.$ ), which

154 leads to overestimated consumption rates. Similarly, the consumption rate is

155 underestimated at high ammoniacal nitrogen concentrations $\left([\mathrm{F}: \mathrm{M}]_{\text {flask }}>[\mathrm{F}: \mathrm{M}]_{\text {reactor }}\right)$.

156 Furthermore, expressing the consumption rate as a function of MLVSS concentration

157 with a flask test is also misleading due to the fact that the MLVSS concentration is not

158 representative of the microbial population consuming the specific studied substrate. In

159 biological treatment systems dealing with complex leachates, the MLVSS contains a

160 mixture of heterotrophic and autotrophic microorganisms. Therefore, since other

161 substrates (ex: $\mathrm{BOD}_{5}, \mathrm{COD}$, etc.) can significantly influence the MVLSS concentrations,

162 the ratio MVLSS:specific substrate is not constant from one study to another. For

163 example, Kaczorek et Ledakowicz (2006) reported a MLVSS concentration of $3.75 \mathrm{~g} \mathrm{~L}^{-1}$

164 in a SBR that treated an effluent containing 1740 to $2240 \mathrm{mg} \mathrm{NH}_{4}-\mathrm{N} \mathrm{L}^{-1}$; on the other

165 hand, He et al. (2009) reported a higher MLVSS $\left(5.5 \mathrm{~g} \mathrm{~L}^{-1}\right)$ in a SMBR that treated an

166 effluent with over 35 times less ammoniacal nitrogen $\left(11-62 \mathrm{mg} \mathrm{NH}_{4}-\mathrm{N} \mathrm{L}^{-1}\right)($ Kaczorek

167 and Ledakowicz 2006, He, Xue et al. 2009).

168 To address these issues, we propose a novel approach to accurately estimate the 169 ammoniacal nitrogen removal kinetic parameters in wastewater biotreatment systems, 170 without having to model all biological processes. The method consists in operating a lab- 
171 scale continuous reactor (SMBR) under steady-state conditions at different effluent

172 ammoniacal nitrogen concentrations. Then, the mass balance equations of the system

173 are solved to calculate the kinetic parameters. The main advantage of this method over

174 the flask test is that the $A O B$ steady-state concentrations in the mixed liquor are in

175 accordance with the tested ammoniacal nitrogen concentrations (the $\mathrm{F}: \mathrm{M}$ ratio is

176 respected for each measurement). Furthermore, inhibitive products such as secondary

177 metabolites that could influence nitritation or nitratation kinetic rates are found in realistic

178 concentrations within the reactor.

179 The main objectives of this study were to: 1) define the mass balance equations of a 180 submerged membrane bioreactor (sMBR), 2) provide an accurate experimental method 181 of measuring kinetic parameters in environmental bioprocesses that treat specific 182 contaminants, and 3) fill the gap in information regarding the kinetics parameters for 183 SMBRs that treat high-strength ammoniacal nitrogen wastewater. Furthermore, a critical 184 comparison between the kinetic parameters measured in this study using the steady185 state approach and those measured by the flask test method reported in the literature is 186 presented. 


\begin{tabular}{|c|c|c|c|c|c|c|c|c|c|c|}
\hline Treatment process & Substrate & $\begin{array}{l}\text { [Ammonia] } \\
\left(\mathrm{mg} \mathrm{NH}_{4}-\mathrm{N} \mathrm{L}^{-1}\right)\end{array}$ & $\begin{array}{l}{[\mathrm{COD}]} \\
\left(\mathrm{mg} \mathrm{O}_{2} \mathrm{~L}^{-1}\right)\end{array}$ & $\begin{array}{l}\text { [MLSS] } \\
(\mathrm{mg} \mathrm{MLSS} \\
\left.\mathrm{L}^{-1}\right) \\
\end{array}$ & Model & $\begin{array}{l}\mathrm{r}_{\mathrm{NH}}\left(0^{\text {th }} \text { order }\right) \\
\left(\mathrm{mg} \mathrm{NH}_{4}-\mathrm{N} \mathrm{L}^{-1}\right. \\
\left.\mathrm{d}^{-1}\right)\end{array}$ & $\begin{array}{l}\mathrm{r}_{\mathrm{NH}, \max } \\
\left(\mathrm{mg} \mathrm{NH}_{4}-\mathrm{N} \mathrm{L}^{-1}\right. \\
\left.\mathrm{d}^{-1}\right)\end{array}$ & $\begin{array}{l}\mathrm{K}_{\mathrm{s}} \\
\left(\mathrm{mg} \mathrm{NH}_{4}-\mathrm{N}\right. \\
\left.\mathrm{L}^{-1}\right)\end{array}$ & $\begin{array}{l}\mathrm{K}_{1} \\
\left(\mathrm{mg} \mathrm{NH} \mathrm{N}_{4}-\mathrm{N}\right. \\
\left.\mathrm{L}^{-1}\right) \\
\end{array}$ & Authors \\
\hline $\begin{array}{l}\text { Suspended growth } \\
\text { activated sludge }\end{array}$ & $\begin{array}{l}\text { synthetic } \\
\text { wastewater }\end{array}$ & $0-100$ & $0-100$ & - & Monod & & 600 & 5,14 & & $\begin{array}{l}\text { (Dinçer and } \\
\text { Kargı 2000) }\end{array}$ \\
\hline \multirow[t]{3}{*}{$\begin{array}{l}\text { Sequencing batch } \\
\text { reactor }\end{array}$} & \multirow[t]{3}{*}{$\begin{array}{l}\text { Mature landfill } \\
\text { leachate ( } 8 \text { years) }\end{array}$} & \multirow[t]{3}{*}{$0-880$} & \multirow[t]{3}{*}{$\begin{array}{l}600- \\
1400\end{array}$} & 9590 & $0^{\text {th }}$ order & 5910 & & & & $\begin{array}{l}\text { (Doyle, Watts } \\
\text { et al. 2001) }\end{array}$ \\
\hline & & & & 3840 & $0^{\text {th }}$ order & 1770 & & & & $\begin{array}{l}\text { (Doyle, Watts } \\
\text { et al. 2001) }\end{array}$ \\
\hline & & & & 4960 & $0^{\text {th }}$ order & 4380 & & & & $\begin{array}{l}\text { (Doyle, Watts } \\
\text { et al. 2001) }\end{array}$ \\
\hline $\begin{array}{l}\text { Suspended growth } \\
\text { activated sludge }\end{array}$ & Synthetic & - & - & 900 & Haldane & & 806,4 & 13 & 284 & $\begin{array}{l}\text { (Carrera, } \\
\text { Jubany et al. } \\
\text { 2004) }\end{array}$ \\
\hline $\begin{array}{l}\text { Immobilized growth } \\
\text { activated sludge }\end{array}$ & Synthetic & - & - & 7300 & Haldane & & 273 & 33 & 1910 & $\begin{array}{l}\text { (Carrera, } \\
\text { Jubany et al. } \\
\text { 2004) }\end{array}$ \\
\hline $\begin{array}{l}\text { Sequencing batch } \\
\text { reactor }\end{array}$ & $\begin{array}{l}\text { Synthetic landfill } \\
\text { leachate }\end{array}$ & $1740-2240$ & $\begin{array}{l}2480- \\
4850\end{array}$ & 3750 & Haldane & & 2381 & 8,45 & 37 & $\begin{array}{l}\text { (Kaczorek and } \\
\text { Ledakowicz } \\
\text { 2006) }\end{array}$ \\
\hline $\begin{array}{l}\text { Simultaneous } \\
\text { nitrification/denitrificat } \\
\text { ion submerged MBR } \\
\text { (SND-sMBR) }\end{array}$ & Synthetic & $11-62$ & $210-650$ & 5500 & $0^{\text {th }}$ order & 161,8 & & & & $\begin{array}{l}\text { (He, Xue et al. } \\
\text { 2009) }\end{array}$ \\
\hline Activated sludge & $\begin{array}{l}\text { Municipal } \\
\text { wastewater }\end{array}$ & $0-600$ & - & 1200 & Haldane & & 135,4 & 59 & 199 & $\begin{array}{l}\text { (Whang, } \\
\text { Chien et al. } \\
\text { 2009) }\end{array}$ \\
\hline $\begin{array}{l}\text { Sequencing batch } \\
\text { reactor }\end{array}$ & Swine wastewater & $0-600$ & - & 3200 & Monod & & 169 & 5 & & $\begin{array}{l}\text { (Whang, } \\
\text { Chien et al. } \\
\text { 2009) }\end{array}$ \\
\hline Membrane bioreactor & $\begin{array}{l}\text { municipal (50\%) and } \\
\text { industrial (50\%) } \\
\text { wastewater }\end{array}$ & $5,6-86,2$ & $\begin{array}{l}150- \\
3000\end{array}$ & $\begin{array}{l}8000- \\
11000\end{array}$ & $0^{\text {th }}$ order & 238 & & & & $\begin{array}{l}\text { (Dvořák, } \\
\text { Svojitka et al. } \\
\text { 2013) }\end{array}$ \\
\hline
\end{tabular}




\section{Material and methods}

\subsection{Membrane bioreactor}

190 The aerated submerged membrane bioreactor (SMBR) and experimental set-up used in

191 this study are shown schematically in Fig. 1.

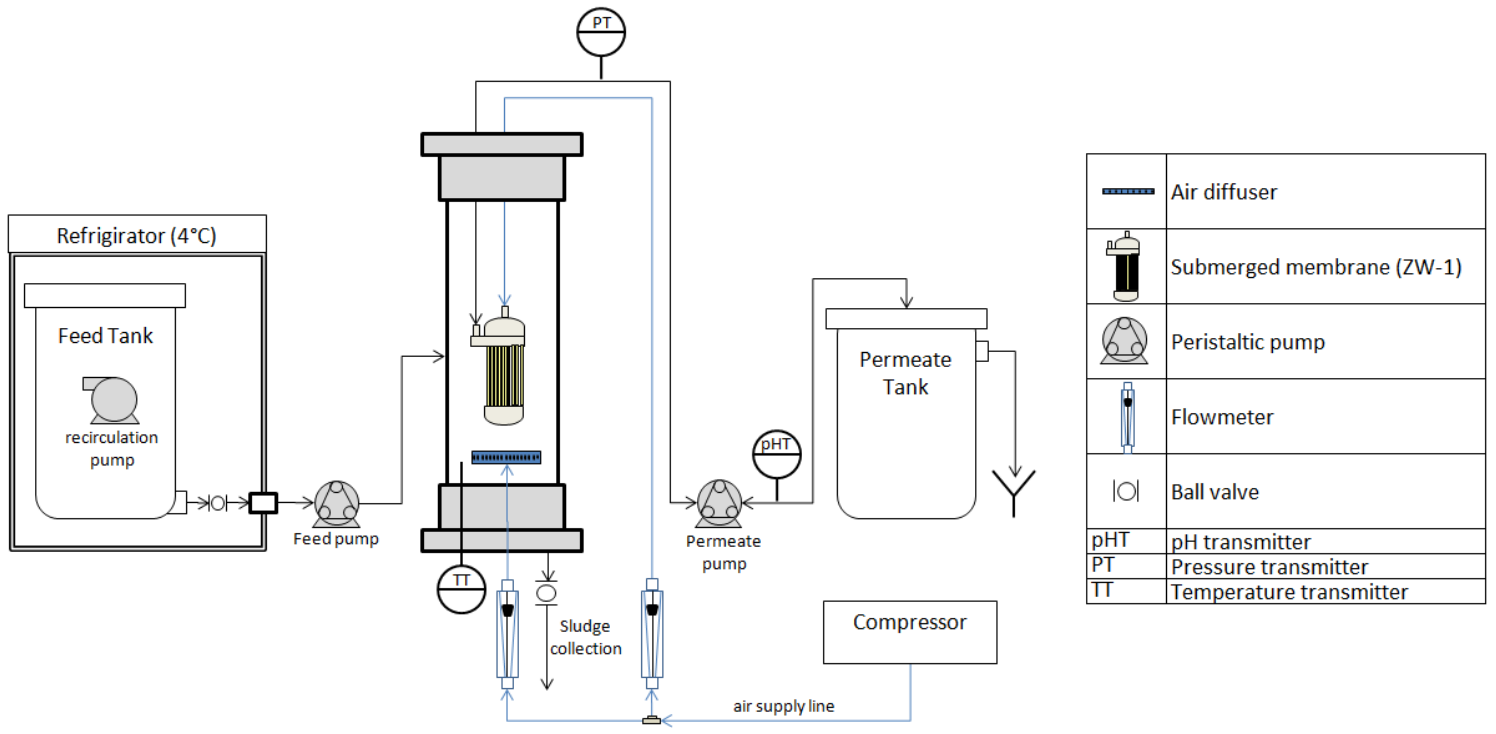

Figure 1 Scheme of the lab-scale sMBR

194 The wastewater was contained in a $50 \mathrm{~L}$ polyethylene tank placed in a refrigerator to

195 maintain its temperature at $4^{\circ} \mathrm{C}$ in order to avoid any biological activity that could alter its

196 composition. The retention time in the tube between the feed tank and the reactor was

197 sufficient for the wastewater temperature to reach room temperature $\left(20 \pm 1^{\circ} \mathrm{C}\right)$ before it

198 was fed to the reactor. A submersible pump was placed at the bottom of the tank to mix

199 the wastewater and avoid the settling of suspended solids.

200 The reactor was made of a $146.33 \mathrm{~mm}$ I.D. clear PVC tube (schedule 80), with a total 201 net capacity of 10 L. Wastewater was fed into the reactor through its side by a peristaltic 
202 pump (Masterflex, model \#7528-10). The membrane was a submerged ultrafiltration 203 hollow-fiber membrane module (Zee-Weed, ZW-1). The membrane's specifications are 204 presented in Table 2.

205 Table 2 Zee-Weed ZW-1 membrane module specifications

\begin{tabular}{lc}
\hline Nominal pore diameter $(\mu \mathrm{m})$ & 0,04 \\
Fiber diameter $(\mathrm{mm})$ & 2 \\
Membrane surface area $\left(\mathrm{m}^{2}\right)$ & 0,047 \\
Maximum transmembrane flux $\left(\mathrm{L}^{*} \mathrm{~m}^{-2} * \mathrm{~h}^{-1}\right)$ & 32 \\
\hline
\end{tabular}

207 A constant permeate flow-rate was obtained by controlling the vacuum applied at the 208 membrane (5 to $50 \mathrm{kPa}$ ) with a peristaltic pump (Masterflex, model \#7528-10). To 209 prevent the accumulation of a cake layer on the membrane surface, the sMBR was 210 operated in filtration/backwash cycles (Filtration: $300 \mathrm{~s}$, flux $7.4 \mathrm{~L} \mathrm{~m}^{-2} \mathrm{~h}^{-1}$, Backwash: 20

$211 \mathrm{~s}$, flux $46.4 \mathrm{~L} \mathrm{~m}^{-2} \mathrm{~h}^{-1}$ ) and air was introduced between the membrane fibers through a 212 perforated pipe within the module $\left(2.5 \mathrm{~L}\right.$ air $\left.\mathrm{min}^{-1}\right)$. Chemical cleaning of the module was 213 conducted when the transmembrane pressure (TMP) reached $-50 \mathrm{kPa}$. It consisted of an 214 oxidation step ( $\mathrm{NaOCl}, 1000 \mathrm{mg} \mathrm{L}^{-1}$ active $\mathrm{Cl}$, recirculation for $3 \mathrm{~h}$ ), and an acidic step 215 (Citric acid, $3 \mathrm{~g} \mathrm{~L}^{-1}$, recirculation for $1.5 \mathrm{~h}$ ).

216 The sMBR was operated in oxic conditions (D.O. $>7 \mathrm{mg} \mathrm{O}_{2} \mathrm{~L}^{-1}$ ) at room temperature $217\left(20 \pm 1^{\circ} \mathrm{C}\right)$. Compressed air was introduced through a perforated tube placed at the 218 bottom in the reactor $\left(2.5 \mathrm{~L} \mathrm{~min}^{-1}\right)$ and arranged in such way as to create a 219 homogeneous internal mixing of the reactor from the rising bubbles. Solid retention time 220 (SRT) control was achieved by discharging excess sludge on a daily basis. Sludge was 221 discharged from the bottom of the reactor in the form of mixed liquor. Hydraulic retention 
222 time (HRT) was controlled by adjusting the flow rates of the feed and the permeate 223 pump, and it was calculated by measuring the collected permeate and mixed liquor 224 volume on a daily basis. The $\mathrm{pH}$ value in the permeate, the TMP, and the activated 225 sludge temperature were measured on-line by the built-in sensors of the experimental 226 set-up and logged every minute.

\section{$227 \quad$ 1.2. Experimental program}

228 The operating conditions of the SMBR during the four different experiment stages are 229 shown in Table 3. During the initial condition (condition \#1), the sMBR was fed with a 230 synthetic leachate containing $219 \pm 3 \mathrm{mg} \mathrm{NH}_{4}-\mathrm{N} \mathrm{L}^{-1}$. Then, the ammoniacal nitrogen 231 concentration in the feed was increased by increments of 120,325 , and $375 \mathrm{mg} \mathrm{NH}_{4}-\mathrm{N}$

$232 \mathrm{~L}^{-1}$ between conditions \#1 to \#4, respectively.

233 Table 3 Operating parameters of the sMBR (average value)

\begin{tabular}{lllll}
\hline Parameters & condition \#1 & condition \#2 & condition \#3 & condition \#4 \\
\hline Period length (d) & 118 & 28 & 32 & 28 \\
MLSS $\left(\mathrm{g} \mathrm{L}^{-1}\right)$ & 3,9 & 4,2 & 3,9 & 4,5 \\
SRT (d) & 31,7 & 30,5 & 28,9 & 32,1 \\
HRT (hr) & 50,4 & 51,3 & 48,8 & 50,1 \\
Ammoniacal nitrogen $\left(\mathrm{mg} \mathrm{NH}_{4}-\mathrm{N} \mathrm{L}^{-1}\right)$ & $219 \pm 3$ & $340 \pm 28$ & $665 \pm 33$ & $1040 \pm 33$ \\
Chemical oxygen demand $\left(\mathrm{mg} \mathrm{L}^{-1}\right)$ & 1096 & 1038 & 1000 & 1047 \\
& & & & \\
NLR (mg NH & & & \\
[C:N] ratio (mg COD : $\left.\mathrm{mg} \mathrm{NH}_{4}-\mathrm{N}\right)$ & $5.0: 1$ & $3.0: 1$ & $1.5: 1$ & $1.0: 1$ \\
\hline
\end{tabular}


235 Condition \#1 lasted for 118 days in order to adapt the mixed liquor to the synthetic 236 leachate and reach steady-state conditions. Then, for conditions \#2 to \#4, the sMBR was 237 operated for 13.5 HRTs (21 days) before taking samples, which is more than the 3 HRTs 238 generally considered to be enough to reach steady-state. Then, samples were taken 239 every day for 7 days. If the difference in removal rates between two samples taken with

240 a 7-day interval was less than 5\%, then the SMBR was considered to be operated at 241 steady-state. Otherwise, the sampling period was extended until that maximum 5\% 242 difference was measured.

243 Once steady-state was achieved, water samples were collected on a daily basis in the 244 feed, the mixed liquor, and the permeate of the lab-scale sMBR. Samples from the feed 245 and permeate were analyzed for ammoniacal nitrogen $\left(\mathrm{NH}_{4}^{+}\right)$, nitrates $\left(\mathrm{NO}_{3}{ }^{-}\right)$, 246 orthophosphates $\left(\mathrm{PO}_{4}{ }^{3-}\right)$, chemical oxygen demand (COD), $\mathrm{pH}$, dissolved oxygen (DO), 247 alkalinity, and solids. Mixed liquor samples were only analyzed for solids.

\subsection{Determining the nitrification kinetics (mass balance)}

249 Mass balance equations are the expression of the relation between the different 250 operating parameters of a process (Fogler 2006). The main parameters involved in the 251 ammoniacal nitrogen mass balance equations of a SMBR that treats high-strength 252 ammoniacal nitrogen wastewaters are shown in Fig. 2. 


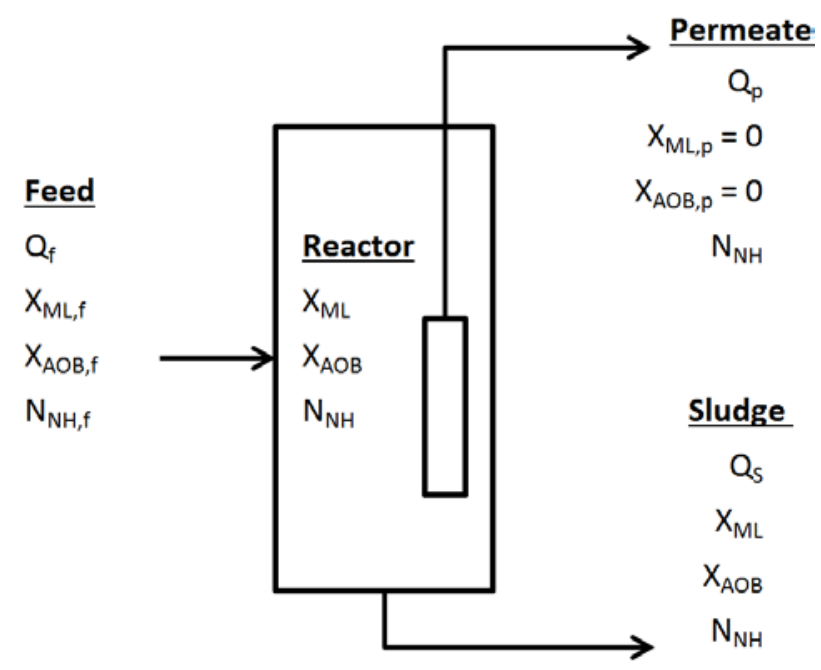

255 Assuming a perfectly mixed continuous stirred tank reactor (CSTR), the ammoniacal 256 nitrogen mass balance is defined as (Eq. 4):

$$
\frac{d N_{N H}}{d t} V=Q_{f} N_{N H, f}-\left(Q_{p} N_{N H}+Q_{S} X_{M L} Y_{N / X}\right)+\int_{0}^{V} r_{N H} X_{A O B} d V
$$

258 Where $\mathrm{Q}$ is the flow rate $\left(\mathrm{L} \mathrm{d}^{-1}\right), \mathrm{N}_{\mathrm{NH}}$ is the ammoniacal nitrogen concentration in the 259 reactor ( $\mathrm{mg} \mathrm{NH}_{4}-\mathrm{N} \mathrm{L}^{-1}$ ), $\mathrm{X}_{\mathrm{ML}}$ is the mixed liquor biomass concentration in the reactor (mg 260 MLVSS $\left.L^{-1}\right), X_{A O B}$ is the AOB concentration in the reactor $\left(\mathrm{mg} \mathrm{L}^{-1}\right), Y_{N / X}$ is the nitrogen 261 content of the biomass in the mixed liquor ( $\mathrm{mg} \mathrm{N} \mathrm{mg} \mathrm{MLVSS}^{-1}$ ), $\mathrm{r}_{\mathrm{NH}}$ is the ammoniacal 262 nitrogen consumption rate $\left(\mathrm{mg} \mathrm{N}-\mathrm{NH}_{4} \mathrm{~g} \mathrm{AOB}^{-1} \mathrm{~d}^{-1}\right)$, and $\mathrm{V}$ is the reactor's volume (L). At 263 steady-state conditions, biomass concentrations $\left(X_{M L}\right.$ and $\left.X_{A O B}\right)$, the reactor's volume 264 and the ammoniacal nitrogen concentration in the reactor are constant $\left(\mathrm{dN}_{\mathrm{NH}} / \mathrm{dt}=0\right)$. Eq. 2654 then becomes (Eq. 5):

$$
Q_{f} N_{N H, f}-\left(Q_{p} N_{N H}+Q_{S} X_{M L} Y_{N / X}\right)=-r_{N H} X_{A O B} V
$$

267 Dividing Eq. 5 by $\vee$ and rearranging, Eq.5 becomes (Eq. 6): 


$$
\frac{N_{N H, f}-N_{N H}}{H R T / 24}-\frac{X_{M L} * Y_{N} / X}{S R T}=-r_{N H} X_{A O B}
$$

269 Where HRT is the hydraulic retention time (hr) and SRT is the solid retention time (d).

270 Assuming that the $\mathrm{AOB}$ concentration and the consumption rate are constant for each

271 given ammoniacal nitrogen concentration (steady-state conditions), the generation term

272 of the equation can be simplified to (Eq. 7):

$$
-r_{N H} X_{A O B}=-r_{N H, i}
$$

274 Where $r_{N H, i}$ is the ammoniacal nitrogen consumption rate $\left(m g N-N_{4} L^{-1} d^{-1}\right.$ ) at the 275 ammoniacal nitrogen concentration "i". The main advantage of using $-r_{\mathrm{NH}, \mathrm{I}}$ over $-\mathrm{r}_{\mathrm{NH}}$ is 276 that it is does not require to know the exact concentration of $A O B$ in the mixed liquor.

277 In this study, the nitrification kinetic parameters were calculated by solving using Eq. 6

278 for $-\mathrm{r}_{\mathrm{NH}, \mathrm{I}}$ (Eq. 7) at 4 steady-state conditions (Table 3) with the lab-scale sMBR system.

279 Then, the results were fitted to the most appropriate biological kinetic model, either 280 Michaelis-Menten (Eq. 2) or Haldane (Eq. 3).

\section{1.4. Synthetic wastewater}

282 The composition of the synthetic leachate used in this study was based on the average 283 composition of a leachate produced over the course of a year at a co-composting facility 284 located in Quebec, Canada. The characterization results of these two leachates are 285 summarized in Table 4.

Table 4 Co-composting facility leachate and synthetic leachate composition

\begin{tabular}{llll}
\hline Parameter & (units) & Co-composting & Synthetic \\
& & facility leachate & leachate \\
\hline Ammoniacal nitrogen & $\mathrm{mg} \mathrm{NH}_{4}-\mathrm{N} \mathrm{L}^{-1}$ & 196 & (see Table 3)
\end{tabular}




\begin{tabular}{|c|c|c|c|}
\hline Condcutivity & $\mathrm{mS} \mathrm{cm}$ & 5.11 & 4.11 \\
\hline $\mathrm{pH}$ & & 6.9 & 7.6 \\
\hline Total Hardness $\left(\mathrm{CaCO}_{3}\right)$ & $\mathrm{mg} \mathrm{L}^{-1}$ & 1386 & $\left(7.5 \times\left[\mathrm{NH}_{4}-\mathrm{N}\right]\right)$ \\
\hline Total Organic Carbon (TOC) & $\mathrm{mg} \mathrm{L}^{-1}$ & 575 & 595 \\
\hline Aluminium (Al) & $\mathrm{mg} \mathrm{L}^{-1}$ & 0.82 & 0.80 \\
\hline Barium (Ba) & $\mathrm{mg} \mathrm{L}^{-1}$ & 0.092 & 0.07 \\
\hline Calcium (Ca) & $\mathrm{mg} \mathrm{L}^{-1}$ & 152 & 109 \\
\hline Copper (Cu) & $\mathrm{mg} \mathrm{L}^{-1}$ & 0.024 & 0.023 \\
\hline Iron (Fe) & $\mathrm{mg} \mathrm{L}^{-1}$ & 12.9 & 13.6 \\
\hline Potassium (K) & $\mathrm{mg} \mathrm{L}^{-1}$ & 435 & 232 \\
\hline Magnesium (Mg) & $\mathrm{mg} \mathrm{L}^{-1}$ & 49.4 & 92.4 \\
\hline Manganese (Mn) & $\mathrm{mg} \mathrm{L}^{-1}$ & 21.4 & 28.8 \\
\hline Sodium (Na) & $\mathrm{mg} \mathrm{L}^{-1}$ & 135 & 572 \\
\hline Nickel (Ni) & $\mathrm{mg} \mathrm{L}^{-1}$ & 0.06 & 0.08 \\
\hline Phosphorus (P) & $\mathrm{mg} \mathrm{L}^{-1}$ & 7.68 & 9.53 \\
\hline Lead (Pb) & $\mathrm{mg} \mathrm{L}^{-1}$ & $<0.0045$ & $<0.0045$ \\
\hline Sulfur (S) & $\mathrm{mg} \mathrm{L}^{-1}$ & 21 & 27.2 \\
\hline Zinc (Zn) & $\mathrm{mg} \mathrm{L}^{-1}$ & 0.078 & 0.0178 \\
\hline
\end{tabular}

288 The following laboratory grade salts were used to prepare the synthetic leachate:

$289 \mathrm{Al}_{2}\left(\mathrm{NH}_{4}\right)_{2}\left(\mathrm{SO}_{4}\right)_{4}, \mathrm{KH}_{2} \mathrm{PO}_{4}, \mathrm{Na}_{2} \mathrm{~B}_{4} \mathrm{O}_{7}, \mathrm{BaCl}_{2}, \mathrm{CoSO}_{4}, \mathrm{CuSO}_{4}, \mathrm{FeCl}_{3}, \mathrm{MgCl}_{2}, \mathrm{MgSO} \mathrm{MnCl}_{2}$,

$290 \mathrm{NiCl}_{2}, \mathrm{Na}_{2} \mathrm{CO}_{3}$ and $\mathrm{KCl}$. The organic carbon in the synthetic leachate was added in the

291 form of ammonium acetate $\left(\mathrm{NH}_{4}\left(\mathrm{CH}_{3} \mathrm{COO}\right)\right)$, calcium propionate $\left(\mathrm{Ca}\left(\mathrm{C}_{2} \mathrm{H}_{3} \mathrm{COO}\right)_{2}\right)$ and

292 acetic acid $\left(\mathrm{CH}_{3} \mathrm{COOH}\right)$. The first $200 \mathrm{mg} \mathrm{NH}_{4}-\mathrm{N} \mathrm{L}^{-1}$ of ammoniacal nitrogen consisted of

293 only ammonium acetate $\left(\mathrm{NH}_{4}\left(\mathrm{CH}_{3} \mathrm{COO}\right)\right)$. Then, for each subsequent concentration

294 increase (conditions \#2 to \#4), ammonium chloride $\left(\mathrm{NH}_{4} \mathrm{Cl}\right)$ was added accordingly. In 
295 order to maintain an adequate $\mathrm{pH}$ for the AOB (above 6.5), the total hardness of the 296 synthetic wastewater was adjusted at each condition using Na2CO3 in order to have a 297 value of $7.5 \mathrm{mg} \mathrm{CaCO}_{3}$ eq. / $\mathrm{mg} \mathrm{NH}_{4}-\mathrm{N}$.

\subsection{Activated sludge growth and adaptation}

299 Activated sludge samples were obtained from a co-composting facility located in 300 Quebec, Canada (Roy, Benkaraache et al. 2019). An initial sample volume of 40L of 301 mixed liquor, with a concentration of approximately $0.25 \mathrm{~g} \mathrm{MLVSS} \mathrm{L}^{-1}$, was taken from 302 the bottom of an aerated lagoon (leachate treatment system) and left to decant for $24 \mathrm{~h}$.

303 Then, the supernatant was removed and solids were transferred in a 20L batch aerated 304 reactor filled with synthetic leachate. Then, over the duration of 4 weeks, the supernatant 305 was replaced every week with $20 \mathrm{~L}$ of fresh synthetic leachate. In order to maintain an 306 adequate concentration of substrate as well as increase the concentration of the 307 biomass in the mixed liquor, $22 \mathrm{~g}$ of ammonium acetate (200 mg NH $\mathrm{NH} \mathrm{L}^{-1}, 343 \mathrm{mg} \mathrm{C}$ org

$\left.308 \mathrm{~L}^{-1}\right)$ and $13.3 \mathrm{~g}$ of calcium propionate $\left(247 \mathrm{mg} \mathrm{C}_{\text {org }} \mathrm{L}^{-1}\right)$ were added every 3 to 4 days. 309 After 4 weeks, the mixed liquor was introduced to the MBR. For a period of 90 days prior 310 to the kinetic experiment, the reactor was fed with synthetic leachate with an

311 ammoniacal concentration of approximately $200 \mathrm{mg} \mathrm{NH}_{4}-\mathrm{N} \mathrm{L}^{-1}$ (Condition \#1, Table 3).

\section{$312 \quad$ 1.6. Control reactor}

313 A control sMBR was run in parallel to the nitrification kinetic experiment in order to 314 distinguish purely chemical removal rates from those associated with the microbial 315 activity. The control experiment was carried out over the course of 48 hours with $10 \mathrm{~L}$ of 316 synthetic leachate in a batch SMBR without mixed liquor. A ZW-1 membrane was used 317 to take permeate samples. $50 \mathrm{~mL}$ samples were taken after $0.25,1,3,6,24$, and 48 
318 hours. Aeration was maintained at $2.5 \mathrm{~L} \mathrm{~min}^{-1}$ through the air diffuser and $2.5 \mathrm{~L} \mathrm{~min}{ }^{-1}$

319 through the membrane module.

320 Two specific parameters were measured: 1) ammoniacal nitrogen concentration, and 2)

321 total phosphorus concentration. Ammoniacal nitrogen is either biologically oxidized by

322 nitrifying bacteria through the nitrification process, assimilated by bacteria in the mixed

323 liquor during cell synthesis (microbial cell element composition: $\mathrm{C}_{60}: \mathrm{O}_{27}: \mathrm{H}_{94}: \mathrm{N}_{15}: \mathrm{P}_{1}$ ), or 324 stripped in the form of ammonia $\left(\mathrm{pKa} \mathrm{NH}_{4}{ }^{+} / \mathrm{NH}_{3}=9.2\right)$. The equilibrium between gas and 325 aqueous phases for the $\mathrm{NH}_{3}$ compounds is the following:

$$
N H_{4(a q)}^{+} \leftrightarrow N H_{3(a q)} \leftrightarrow N H_{3(g)} ; p K a N H_{4}^{+} / N H_{3}=9.2
$$

326 Phosphorus removal is generally obtained either through co-precipitation with multivalent 327 metals $\left(\mathrm{Fe}_{2}^{+}, \mathrm{Fe}_{3}^{+}, \mathrm{Al}_{3}^{+}\right)$, struvite formation with ammonium and magnesium $328\left(\mathrm{NH}_{4} \mathrm{MgPO}_{4}\right)\left(\right.$ Huang, Xiao et al. 2014), adsorption on metal hydroxide colloids $\left(\mathrm{Fe}(\mathrm{OH})_{3}\right.$, $\left.329 \mathrm{Al}(\mathrm{OH})_{3}\right)$, or by assimilation during cell synthesis.

\subsection{Analytical methods}

331 The samples were analyzed for $\mathrm{pH}$ (Mettler Toledo SevenEasy), electrical conductivity 332 (Mettler Toledo SevenCompact Conductivity), alkalinity (bromocresol green titration), 333 solid content (total, dissolved, and volatile)(EPA Method 160.2), chemical oxygen 334 demand (CEAEQ MA. 315 - DCO 1.1, Potassium dichromate), dissolved ammoniacal 335 nitrogen (QuickChem Method 10-107-06-2-O, salicylate - nitroprusside colorimetric 336 method), dissolved ortho-phosphate (QuickChem Method 10-115-01-1-B), dissolved 337 nitrites/nitrates (QuickChem Method 10-107-04-2-B), and total metals (22 metals) and 338 phosphorus (Varian Vista AX ICP-AES). Total metal and phosphorus contents were 
339 determined after preliminary sample digestion (15\% trace metals grade $\mathrm{HNO}_{3}$ and $5 \%$ $340 \quad \mathrm{H}_{2} \mathrm{O}_{2}$ at $95^{\circ} \mathrm{C}$ for 2 hours).

\section{$341 \quad$ 2. Results and discussion}

\section{2.1. Control reactor experiment}

343 The evolution of the ammoniacal nitrogen concentration in the control reactor over a 48 344 hour period is presented in Fig. 3. The initial ammoniacal nitrogen concentration 345 measured in the control SMBR was $946 \pm 7 \mathrm{mg} \mathrm{NH} \mathrm{NH} \mathrm{L}^{-1}$. Over the duration of the 346 experiment, the concentration of ammoniacal nitrogen decreased by approximately $7 \mathrm{mg}$ $347 \mathrm{NH}_{4}-\mathrm{N} \mathrm{L}^{-1}$, which corresponds to a $0.7 \%$ loss. With an initial $\mathrm{pH}$ of 7.6 , the quantity of 348 ammonia $\left(\mathrm{NH}_{3(\mathrm{aq})}\right)$ is negligible in the aqueous phase and gaseous phase. Furthermore, 349 the nitrification reaction in the presence of mixed liquor acidifies the solution, which 350 reduces even further the $\mathrm{pH}$ and favors the $\mathrm{NH}_{4}{ }^{+}$(aq) form. Thus, the variation observed in 351 the control reactor is most likely associated with a chemical precipitation in the form of 352 inorganic salts such as struvite. 


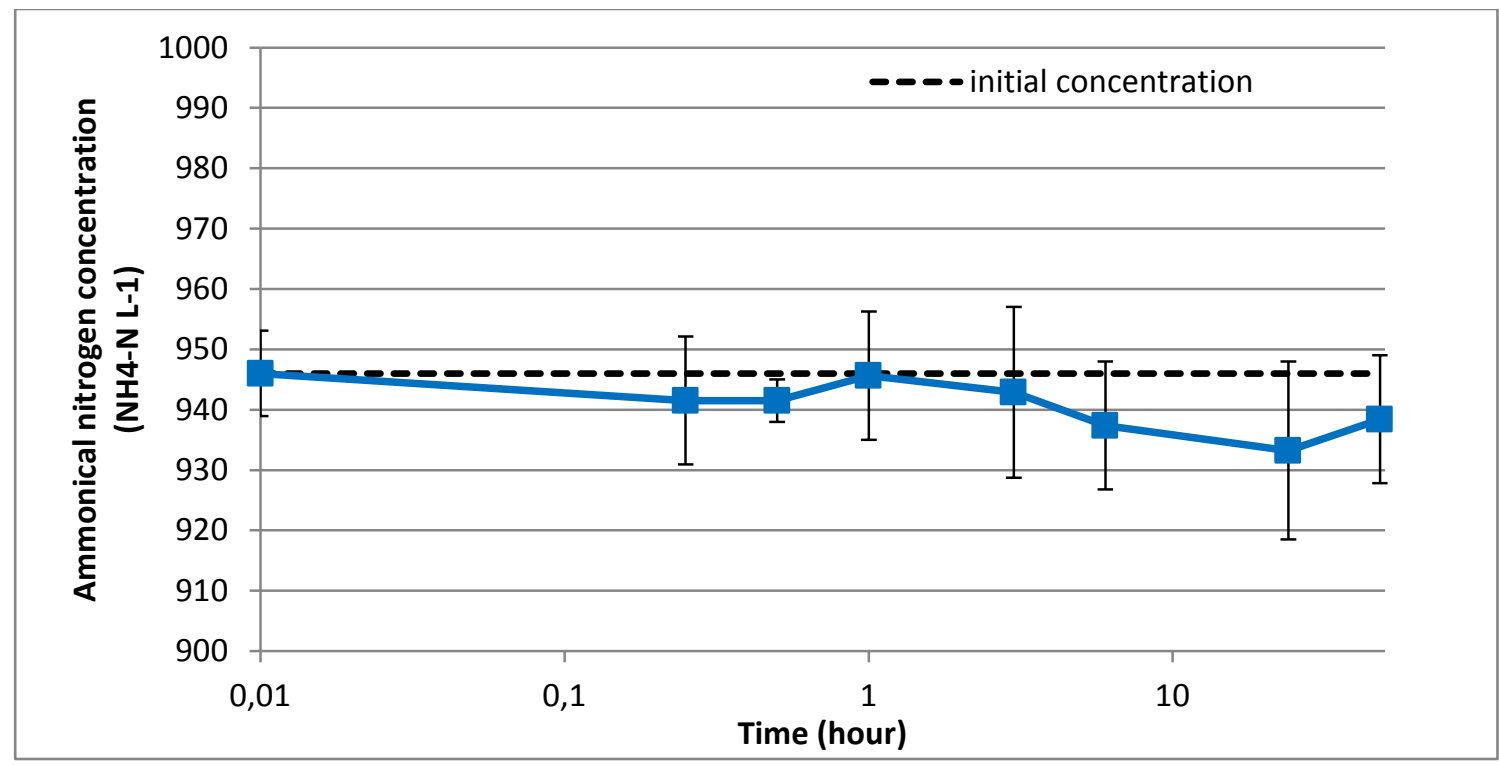

354 Figure 3 Evolution of the ammoniacal nitrogen concentrations in the control reactor

355 In terms of the phosphorus, the concentration of soluble phosphorus in the form of 356 orthophosphate in the control sMBR decreased from $9 \mathrm{mg} \mathrm{PO}_{4}-\mathrm{P} \mathrm{L}^{-1}$ to $3.4 \mathrm{mg} \mathrm{PO}_{4}-\mathrm{P} \mathrm{L}^{-1}$ 357 after 15 minutes, and decreased further to $0.76 \mathrm{mg} \mathrm{PO}_{4}-\mathrm{P} \mathrm{L}^{-1}$ after 48 hours. Table 5 358 shows the measured concentrations of the major elements present in the synthetic 359 leachate. After 48 hours, aluminum, manganese and iron concentrations decreased by $36080 \%, 92 \%$, and more than $99.9 \%$, respectively, while total phosphorus concentration 361 decreased from 9 to $0.8 \mathrm{mg} \mathrm{P} \mathrm{L}^{-1}$. These results indicate the formation of insoluble 362 inorganic molecules containing negatively charged orthophosphate ions and multivalent 363 metal ions. The molar ratio of removed ammoniacal nitrogen (N):ortho-phosphates 364 (P):magnesium (1:1.74:0.76) confirms that ammoniacal nitrogen reduction could be 365 attributed to the formation of struvite. The results obtained from this control reactor 366 experiment support the hypothesis that ammoniacal nitrogen concentration variations in 367 the SMBR during the kinetic study are only attributed to the biological nitrification or 368 assimilation, while phosphorus removal can only be attributed to chemical precipitation. 


\begin{tabular}{llllllllll}
\hline & \multicolumn{8}{c}{ Metals $\left(\mathrm{mg} \mathrm{L}^{-1}\right)$} \\
\cline { 2 - 6 } & Al & Ca & Fe & K & Mg & Mn & Na & P \\
\hline 0 & 0.75 & 115 & 14.9 & 240 & 84 & 47 & 624 & 9.0 \\
0.25 & 0.40 & 122 & 0.12 & 240 & 74 & 4.0 & 626 & 3.3 \\
1 & 0.15 & 108 & 0.04 & 234 & 70 & 3.8 & 604 & 2.8 \\
24 & 0.16 & 109 & 0.03 & 232 & 68 & 3.3 & 620 & 1.5 \\
48 & 0.15 & 109 & $<0.01$ & 218 & 63 & 3.6 & 630 & 0.8 \\
\hline
\end{tabular}

370

\section{2. $\quad$ Nitrification kinetic experiments}

\subsubsection{SMBR performances}

373 To define the nitrification kinetic parameters in a SMBR that treats high strength

374 ammoniacal nitrogen wastewaters, the lab-scale submerged SMBR was fed with

375 synthetic leachate at 4 different initial ammoniacal nitrogen concentrations (220, 340,

376665 and $1040 \mathrm{mg} \mathrm{NH}-\mathrm{N} \mathrm{L}^{-1}$ ) with a constant HRT. The selected ammoniacal nitrogen

377 concentration range is based on the concentration reported in the literature for

378 composting leachates originating from green wastes and mixed municipal solid wastes

379 (Roy, Azaïs et al. 2018). Fig. 4 presents the ammoniacal nitrogen mass balance and 380 removal rates obtained from this experiment. Over the first 118 days, the reactor was 381 operated with a HRT of $48 \pm 3 \mathrm{hr}$, a SRT of $30 \pm 2 \mathrm{~d}$ and a NLR of $108 \mathrm{mg} \mathrm{NH}_{4}-\mathrm{N} \mathrm{L}^{-1} \mathrm{~h}^{-1}$ $382\left(\left[\mathrm{NH}_{4}\right]=220 \mathrm{mg} \mathrm{NH} \mathrm{NH}_{4}-\mathrm{N} \mathrm{L}^{-1}\right)$ to develop an acclimated mixed liquor. Toward the end of 383 this period, the constant MLVSS measured in the SMBR indicated that the growth of new 384 bacteria was equal to the combination of cell decay and the amount of sludge removed 
385 in order to maintain a constant SRT. With the absence in variation of MLVSS, and the 386 entire consumption of both the ammonia and the COD, it was assumed that the 387 heterotrophic and autotrophic bacteria populations reached their equilibrium in the mixed 388 liquor. Therefore, the F:M ratios were constant for all substrates. Then, at day 119, 148 389 and 193, the NLR was increased to 163,330 and $509 \mathrm{mg} \mathrm{NH}_{4}-\mathrm{N} \mathrm{L}^{-1} \mathrm{~d}^{-1}$, respectively.

390 After each increase, the reactor was operated for 28 days in order to achieve a steady-

391 state operation, which is required to solve the mass balance equation and define the 392 nitrification kinetic parameters. Fig. 4 a. shows the constant removal rates $(<5 \%$ 393 difference between 2 samples with a 7-day interval) observed at the end of each 394 experimental condition, thus confirming the achievement of a steady-state operation of 395 the SMBR.

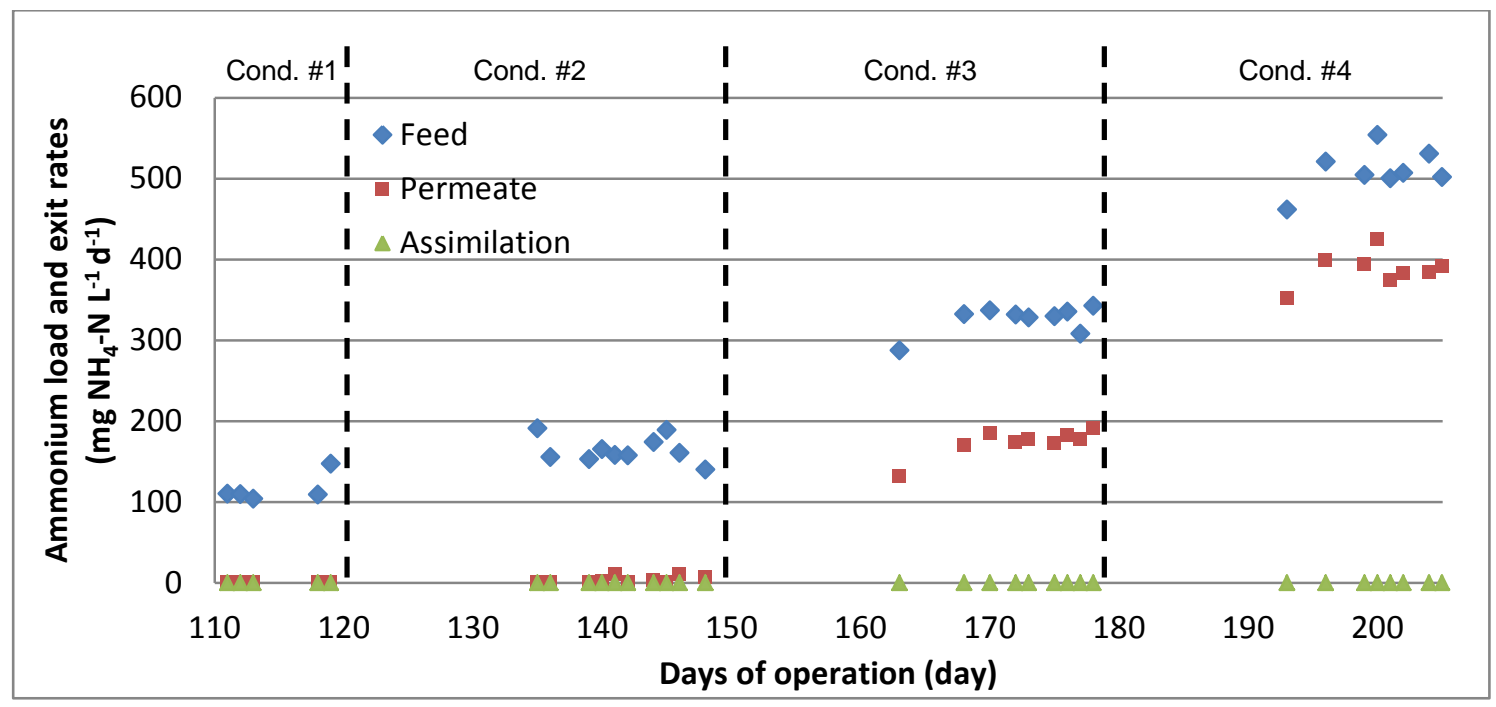

(a) 


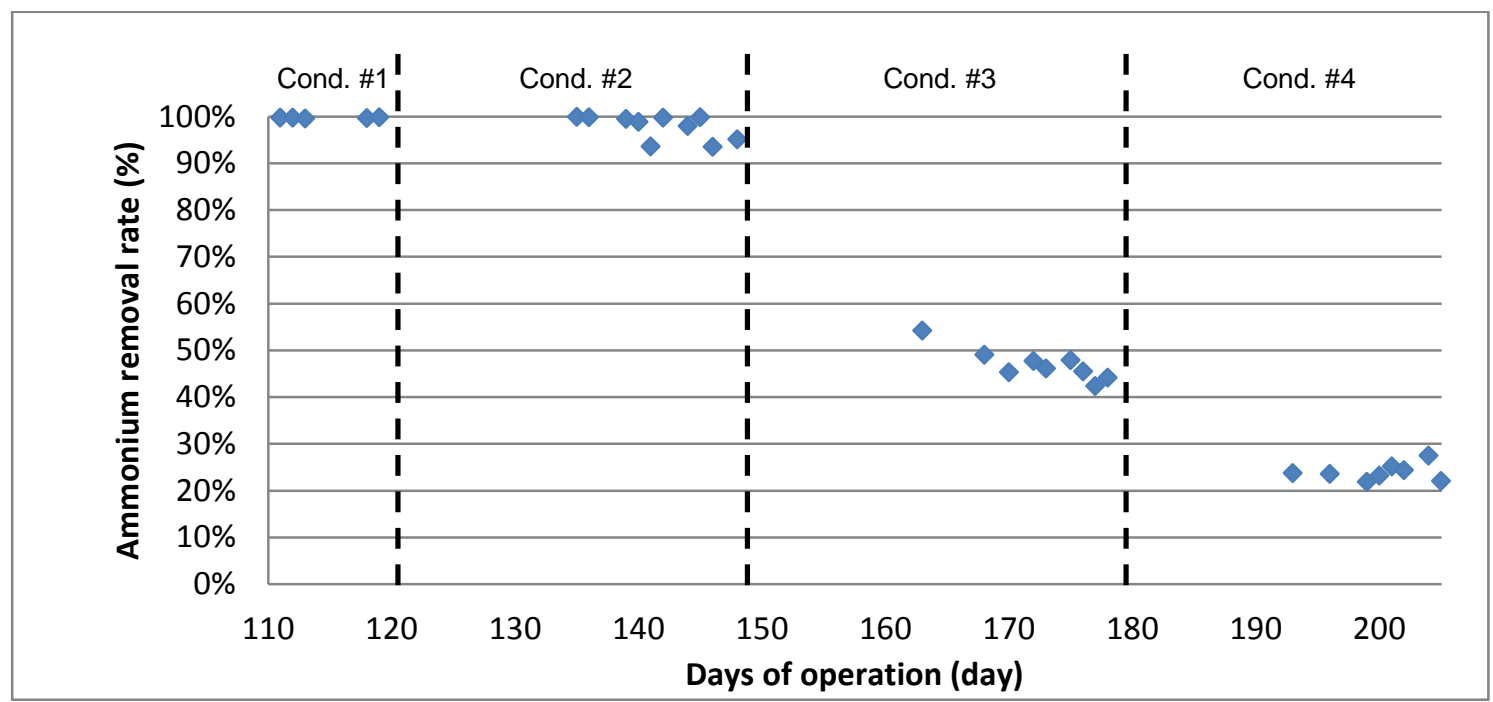

(b)

Figure 4 Ammoniacal nitrogen load and exit rates and Fig. 4 b) Ammoniacal nitrogen removal performances of

399 The ammoniacal nitrogen load and exit rates, as well as the average removal rates for 400 each of the 4 experimental conditions are presented in Table 6. For NLRs below $165 \mathrm{mg}$ $401 \mathrm{NH}_{4}-\mathrm{N} \mathrm{L}^{-1} \mathrm{~d}^{-1}$ (Conditions \#1 and \#2), the removal rates were of $99.7 \%$ and $97.8 \%$, which 402 corresponds to the range reported in the literature. However, the removal rates 403 decreased to $46.1 \%$ and $23.8 \%$ with NLRs of 330 and $509 \mathrm{mg} \mathrm{NH}_{4}-\mathrm{N} \mathrm{L}^{-1} \mathrm{~d}^{-1}$, 404 respectively. These results indicate that for load rates above $160 \mathrm{mg} \mathrm{NH}_{4}-\mathrm{N} \mathrm{L}^{-1} \mathrm{~d}^{-1}$, there 405 is an excess of substrate for the AOB present in the mixed liquor, and any subsequent 406 ammoniacal nitrogen fed to the reactor is not oxidized. Furthermore, the $28 \%$ decrease 407 in ammoniacal nitrogen consumption between condition \#2 (160 mg NH $\mathrm{NH} \mathrm{L}_{4}^{-1} \mathrm{~d}^{-1}$ 408 consumed) and \#4 (115 $\mathrm{mg} \mathrm{NH}_{4}-\mathrm{N} \mathrm{L}^{-1} \mathrm{~d}^{-1}$ consumed), despite an increase in NLR, 409 indicates a significant inhibition effect of the ammoniacal nitrogen at NLRs higher than $410160 \mathrm{mg} \mathrm{NH}_{4}-\mathrm{N} \mathrm{L}^{-1} \mathrm{~d}^{-1}$.

411 Since all nitrogen fed to the reactor was in the form of ammoniacal nitrogen, nitrogen 412 assimilated into the biomass/mixed liquor must be taken into account in the ammoniacal 
413 nitrogen mass balance equations. Elementary composition analyses were conducted on

414 dried mixed liquor samples collected from the SMBR. On average, mixed liquor contains

$41534 \% \mathrm{C}, 7,5 \% \mathrm{Ca}, 6 \% \mathrm{~N}, 1.5 \% \mathrm{P}$ and $7.5 \%$ of other metals (Al, Fe, K, Mg, Mn, Na, S, Si).

416 The remaining $14 \%$ is oxygen and hydrogen. Nitrogen assimilated by the biomass in the

417 mixed liquor (calculated from Eq. 6) corresponds to approximately $0.01 \%$ of the total

418 nitrogen fed to the reactor. Thus, ammoniacal nitrogen is almost entirely used as a

419 source of energy by $A O B$, and it is reasonable to neglect the nitrogen assimilated by the

420 biomass when calculating ammoniacal nitrogen removal kinetics parameter in reactors

421 treating high-strength ammonia wastewater with high NLR and long SRT (>30 days).

422 Table 6 Ammoniacal nitrogen mass balance for the MBR

\begin{tabular}{|c|c|c|c|c|c|}
\hline \multirow{2}{*}[\mathrm{NH}_{4}]{$_{\mathrm{feed}}$} & \multirow{2}{*}{$\begin{array}{l}\text { Load rate } \\
\text { Feed }\end{array}$} & \multicolumn{2}{|l|}{ Exit rates } & \multicolumn{2}{|l|}{ Removal } \\
\hline & & Permeate & Assimilation & Assimilation & Total \\
\hline & $\left(\mathrm{mg} \mathrm{NH}_{4}-\mathrm{N} \mathrm{L}^{-1} \mathrm{~d}^{-}\right.$ & $\left(\mathrm{mg} \mathrm{NH}_{4}-\mathrm{N} \mathrm{L}^{-1} \mathrm{~d}^{-}\right.$ & $\left(\mathrm{mg} \mathrm{NH}_{4}-\mathrm{N} \mathrm{L}^{-1} \mathrm{~d}^{-}\right.$ & & \\
\hline$\left(\mathrm{mg} \mathrm{NH}_{4}-\mathrm{N} \mathrm{L}^{-1}\right)$ & $\left.{ }^{1}\right)$ & $\left.{ }^{1}\right)$ & $\left.{ }^{1}\right)$ & (\%) & (\%) \\
\hline $219 \pm 3$ & 108 & 0,36 & 0,008 & 0,01 & 99,7 \\
\hline $340 \pm 28$ & 163 & 3,5 & 0,009 & 0,01 & 97,8 \\
\hline $665 \pm 33$ & 330 & 178 & 0,008 & $<0,01$ & 46,1 \\
\hline $1040 \pm 33$ & 509 & 394 & 0,009 & $<0,01$ & 23,8 \\
\hline
\end{tabular}

423

$424 \quad$ 2.2.2. Nitrification kinetics modeling

425 Specific ammoniacal nitrogen oxidation rates $\left(\mathrm{r}_{\mathrm{NH}, \mathrm{i}}\right)$ were calculated from Eq. 6 for each 426 sample taken during the steady-state operation of the sMBR at 4 different initial 427 ammoniacal nitrogen concentrations $\left(\mathrm{N}_{\mathrm{NH}, \mathrm{f}}=[220-1040] \mathrm{mg} \mathrm{NH}_{4}-\mathrm{N} \mathrm{L}^{-1}\right)$ (Fig. 5). 


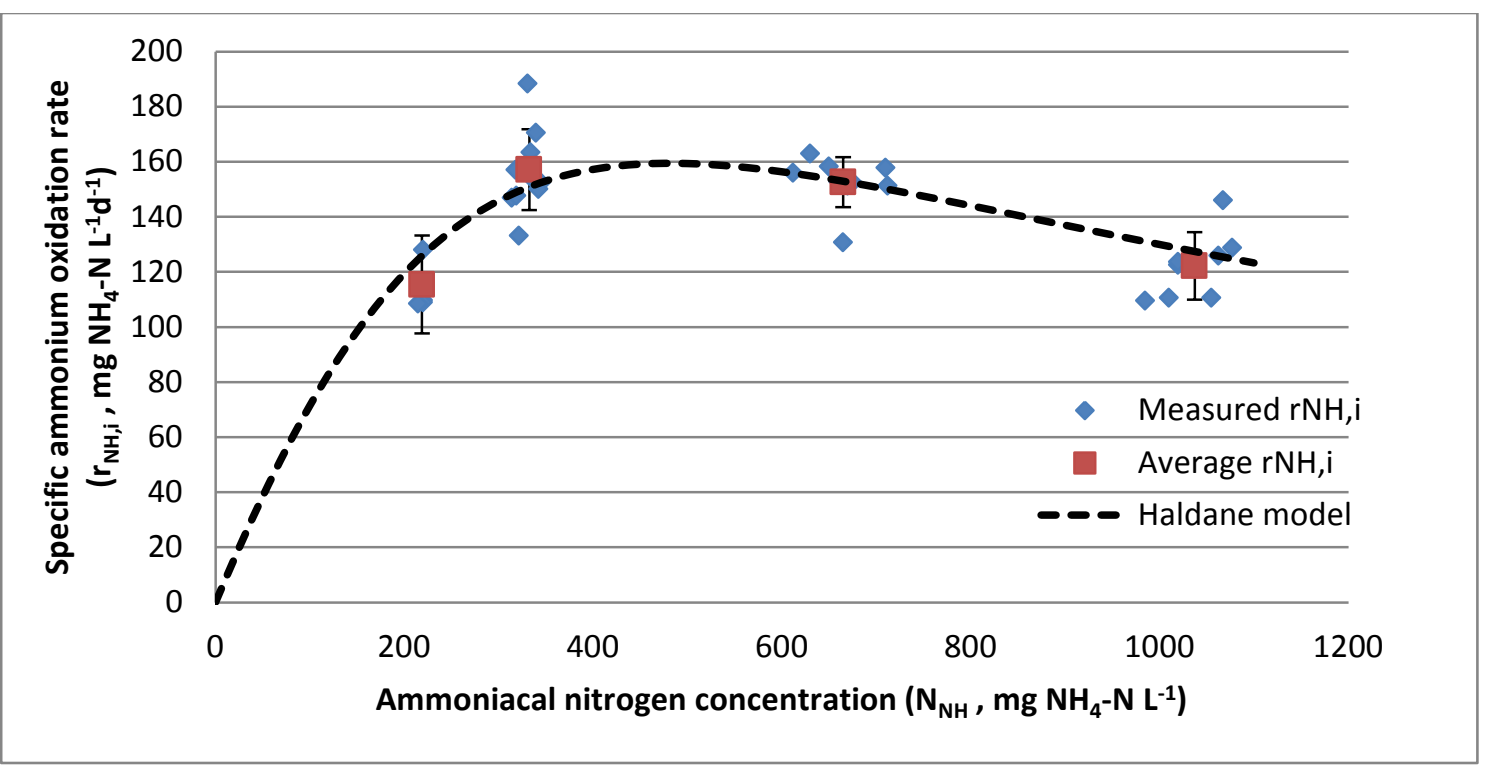

430 Results presented in Fig. 5 clearly indicate that the specific ammoniacal nitrogen 431 oxidation rates were affected by the ammoniacal nitrogen concentration in the treated 432 wastewater. For initial ammoniacal nitrogen concentrations ranging from 200 to $400 \mathrm{mg}$ $433 \mathrm{NH}_{4}-\mathrm{N} \mathrm{L}^{-1}$, the specific oxidation rates increased from $115 \pm 17$ to $161 \pm 18 \mathrm{mg} \mathrm{NH}_{4}-\mathrm{N} \mathrm{L}^{-1} \mathrm{~d}^{-}$ 434 . Then, the specific oxidation rates decreased to $153 \pm 9$ and $122 \pm 12 \mathrm{mg} \mathrm{NH}_{4}-\mathrm{N} \mathrm{L}^{-1} \mathrm{~d}^{-1}$ at 435 initial ammoniacal nitrogen concentrations of 665 and $1040 \mathrm{mg} \mathrm{NH}_{4}-\mathrm{N} \mathrm{L}^{-1}$, respectively. 436 The negative variation of the specific oxidation rates at ammoniacal nitrogen 437 concentrations above $400 \mathrm{mg} \mathrm{NH}_{4}-\mathrm{N} \mathrm{L}^{-1}$ are suspected to be caused by an inhibition 438 phenomenon due to an excess in substrate concentration or a nitrite production which 439 inhibits nitritation reaction, as observed by Gagnaire et al. in a flask test study(Gagnaire, 440 Wang et al. 2011).

441 In order to take the inhibition phenomena into account, the Haldane model was selected 442 to predict the specific ammoniacal nitrogen oxidation rates (Eq. 3). The 3 kinetic 443 parameters of the model $\left(\mathrm{r}_{\mathrm{NH} \text {,max }}, \mathrm{K}_{\mathrm{H}}\right.$ and $\left.\mathrm{K}_{\mathrm{l}}\right)$ were obtained by fitting the experimental 444 data (32 measurements) to the Haldane model equation. The calculated kinetic 
445 parameters are: $\mathrm{r}_{\mathrm{NH}, \text { max }}=854,4 \mathrm{mg} \mathrm{NH}_{4}-\mathrm{N} \mathrm{L}^{-1} \mathrm{~d}^{-1}, \mathrm{~K}_{\mathrm{S}}=1007 \mathrm{mg} \mathrm{NH}_{4}-\mathrm{N} \mathrm{L}^{-1}$, and $\mathrm{K}_{\mathrm{I}}=221$

$446 \mathrm{mg} \mathrm{NH}-\mathrm{N} \mathrm{L}^{-1}\left(\mathrm{R}^{2}=0,97\right)$. The Haldane model is reported in Fig. 5. According to the

447 model's equation, the lower the value of inhibition coefficient $\left(\mathrm{K}_{\mathrm{l}}\right)$, the more significant

448 the inhibition is. The $\mathrm{K}_{\mathrm{I}}$ calculated in this study is in accordance with values reported in

449 the literature for suspended growth mixed liquors. For example, Carrera et al. (2004) and

450 Whang et al. (2009) both reported $K_{1}$ values for activated sludge systems of 284 and 199

$451 \mathrm{mg} \mathrm{NH}_{4}-\mathrm{N} \mathrm{L}^{-1}$, respectively (Carrera, Jubany et al. 2004, Whang, Chien et al. 2009).

452 The ammoniacal nitrogen concentration for which the oxidation rate is at its highest is 453 obtained by finding the root of the derivative of the model's equation $\left(\mathrm{dr}_{\mathrm{NH}, \mathrm{I}} / \mathrm{dN}_{\mathrm{NH}}=0\right)$.

454 The following relationship is obtained (Eq. 8):

$$
N_{N H, o p t}=\sqrt{\left(K_{S} K_{I}\right)}
$$

456 According to Eq. 8, the highest specific nitrification rate of a sMBR to treating high457 strength ammoniacal nitrogen leachate is obtained at an initial concentration of $472 \mathrm{mg}$ $458 \mathrm{NH}_{4}-\mathrm{N} \mathrm{L}^{-1}$. Above this concentration, the inhibition phenomena negatively impact the 459 nitrification rates. In terms of reactor design, this concentration corresponds to the 460 optimal HRT:NLR ratio, and any higher ammoniacal nitrogen concentration will require a 461 larger reactor's volume per mass of contaminants to achieve the desired treated water 462 quality.

464 Kinetic parameters measured in this study were compared to those reported in the 465 literature for systems treating high-strength ammoniacal nitrogen wastewater. Fig. 6 466 shows the specific ammonium oxidation rates reported for 5 flask test studies (Carrera, 467 Jubany et al. 2004, Kaczorek and Ledakowicz 2006, He, Xue et al. 2009, Whang, Chien 
469 Kargı 2000), and compares them to the experimental data obtained in this study.

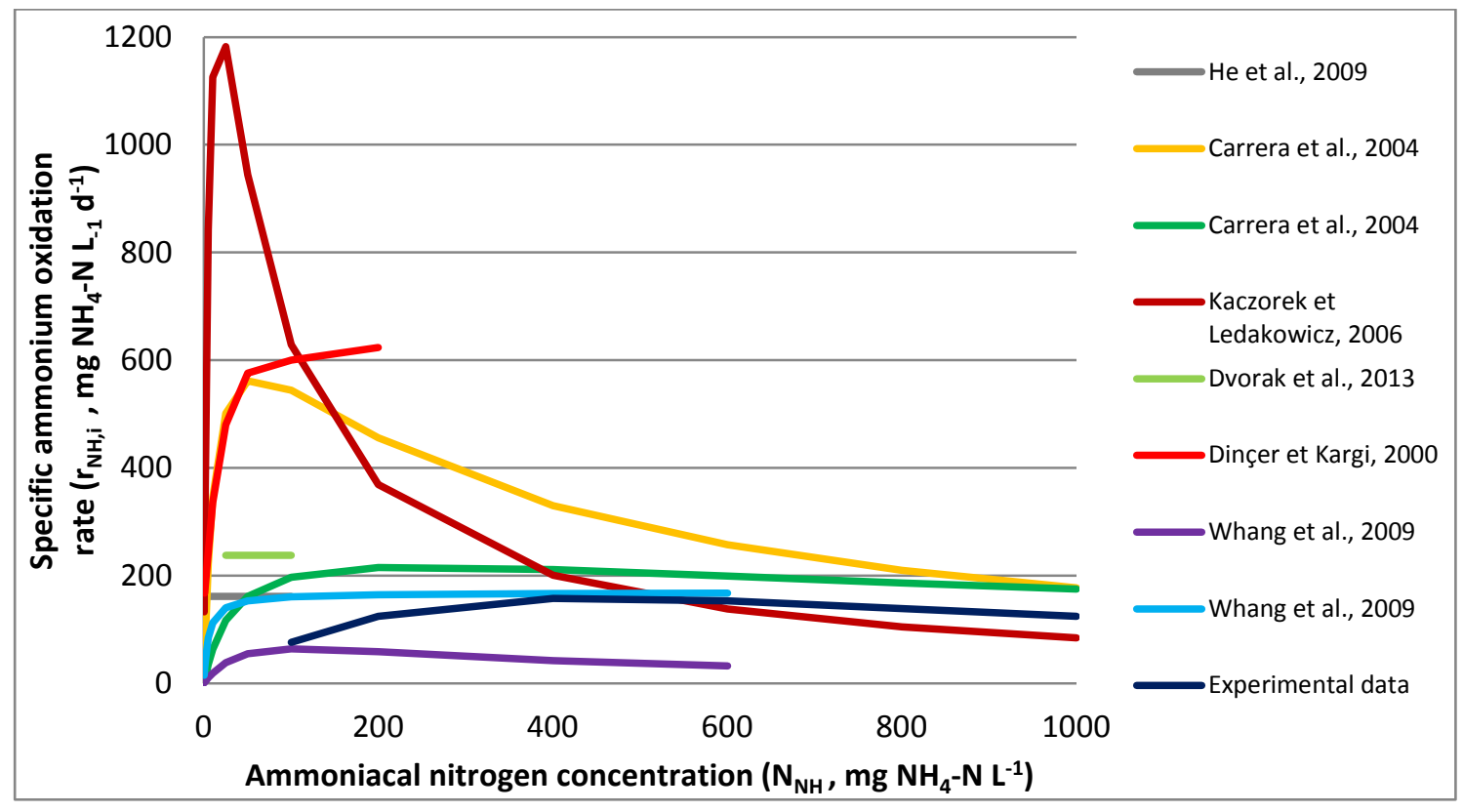

471 Figure 6 Comparison between ammoniacal nitrogen oxidation rates reported from the literature and those 472 measured in this study

473 Dvorak et al. (2013) and He et al.(2009) both reported $0^{\text {th }}$ order kinetics since, they only 474 worked on short concentration ranges (5.6 to $\left.86.2 \mathrm{mg} \mathrm{NH}_{4}-\mathrm{N} \mathrm{L}^{-1}\right)(\mathrm{He}, \mathrm{Xue}$ et al. 2009, 475 Dvořák, Svojitka et al. 2013). Therefore, their reported oxidation rates are only valid for 476 that range and cannot be compared to other reported values at higher ammoniacal 477 nitrogen concentrations $\left(>100 \mathrm{mg} \mathrm{NH}_{4}-\mathrm{N} \mathrm{L}^{-1}\right)$.

478 As previously mentioned, the proportion of the AOB population in the mixed liquor is 479 directly proportional to the overall ammoniacal nitrogen oxidation rate (Eq. 7). In a 480 previous study, Munz et al. (2010) showed that the AOB growth rate and concentration 481 in the mixed liquor are proportional to the ammoniacal nitrogen concentration in the 482 treated effluent (Munz, Mori et al. 2010). Therefore, in order to compare the mixed 483 liquors used in the different studies reported in Fig. 6, the NLR and the corresponding 
484 ammoniacal nitrogen concentrations treated by the reactors from which the mixed liquor

485 was taken have been summarized in Table 7.

486 Table 7 Ammoniacal nitrogen load rates (NLR) of reactors treating high-strength ammoniacal nitrogen

NLR HRT $\quad[\mathrm{NH} 4]$

\section{Authors}

\section{$\left(m g \mathrm{NH}_{4}-\mathrm{N} \mathrm{L}^{-1} \mathrm{~d}^{-1}\right) \quad$ (h) $\quad\left(\mathrm{mg} \mathrm{NH}_{4}-\mathrm{N} \mathrm{L}^{-1}\right)$}

Carrera et al. (2004) (Carrera, Jubany et al.

$\begin{array}{llll}\text { 2004)(Yellow curve) } & 90 & 48 & 180\end{array}$

Kackzorek et Ledakowicz (2006) (Kaczorek

and Ledakowicz 2006)

240

$72 \quad 720$

Dvorak et al. (2013) (Dvořák, Svojitka et al.

$54-80$

$14 \quad 31-47$

Whang et al. (2009) (Whang, Chien et al.

2009) (Blue curve)

43

10

18

Whang et al. (2009) (Whang, Chien et al.

2009) (Purple curve)

107

$48 \quad 214$

488 According to the different NLR, higher concentrations of $A O B$ in the mixed liquor from 489 Kaczorek et Ledakowicz (2006) would be expected when compared to any other mixed 490 liquor reported in Table 7, since their reported NLR was the highest. This hypothesis 491 only stands if the duration of the SRT was sufficient to maintain the AOB population 492 within the reactor. To measure the specific ammoniacal nitrogen oxidation rate $\left(\mathrm{r}_{\mathrm{NH}, \mathrm{i}}\right)$, 493 Kaczorek et Ledakowicz (2006) measured the consumption rate by exposing the mixed 494 liquor from their reactor, which was adapted to an ammoniacal nitrogen concentration of $495720 \mathrm{mg} \mathrm{NH}_{4}-\mathrm{N} \mathrm{L}^{-1}$, to a wide range of ammoniacal nitrogen concentrations. This 
496 approach provides an accurate estimation of the specific ammoniacal nitrogen oxidation 497 rate at concentrations close to that of the treated effluent $( \pm 20 \%)$. However, at low 498 substrate concentration, the F:M ratio is unrealistically low, which leads to highly 499 overestimated rates. This is what explains Kaczorek et Ledakowicz's (2006) reported 500 rate of $1217 \mathrm{mg} \mathrm{NH}_{4}-\mathrm{N} \mathrm{L}^{-1} \mathrm{~d}^{-1}$ with an effluent concentration of $17.7 \mathrm{mg} \mathrm{NH}_{4}-\mathrm{N} \mathrm{L}^{-1}$ 501 (Kaczorek and Ledakowicz 2006). The mixed liquor used in their study was taken from a 502 reactor treating a wastewater containing $720 \mathrm{mg} \mathrm{NH}_{4}-\mathrm{N} \mathrm{L}^{-1}$ with a NLR of $240 \mathrm{mg} \mathrm{NH}_{4}-\mathrm{N}$ $503 \mathrm{~L}^{-1} \mathrm{~d}^{-1}$. In this case, the $\mathrm{F}: \mathrm{M}$ ratio $([\mathrm{NH} 4]$ : $\mathrm{AOB})$ in the flask at concentrations lower than $504400 \mathrm{mg} \mathrm{NH}_{4}-\mathrm{N} \mathrm{L}^{-1}$ was unrealistically low, which led to a highly overestimated oxidation 505 rate when compared to similar studies. On the other hand, the $r_{\mathrm{NH}, \mathrm{I}}$ that they reported at 506 concentrations around $720 \mathrm{mg} \mathrm{NH}_{4}-\mathrm{N} \mathrm{L}^{-1}$ were in the same range as most of the 507 reported values.

508 Similarly, Whang et al. (2009) studied the nitrification kinetics of mixed liquor taken from 5092 treatment systems treating municipal wastewaters (Fig. 6, blue curve) and swine 510 wastewater (Fig. 6, purple curve) (Whang, Chien et al. 2009). In both case, the same 511 volume of mixed liquor was taken from each reactor to conduct the flask tests, despite 512 the difference in NLR fed to both treatment systems. As expected, the ratio of the 513 highest reported $\mathrm{r}_{\mathrm{NH}, \mathrm{I}}$ from each reactor $\left(168 \mathrm{mg} \mathrm{NH}_{4}-\mathrm{N} \mathrm{L}^{-1} \mathrm{~d}^{-1} / 65 \mathrm{mg} \mathrm{NH}_{4}-\mathrm{N} \mathrm{L}^{-1} \mathrm{~d}^{-1}=\right.$ $5142.58)$ is almost equal to the ratio of the NLR of the reactors $\left(107 \mathrm{mg} \mathrm{NH}_{4}-\mathrm{N} \mathrm{L}^{-1} \mathrm{~d}^{-1} / 43\right.$ $515 \mathrm{mg} \mathrm{NH} \mathrm{NH} \mathrm{L}^{-1} \mathrm{~d}^{-1}=2.49$ ). Assuming that the $\mathrm{AOB}$ population in the mixed liquor is 516 proportional to the NLR, these ratios show that both reactors have a similar capacity of 517 removing ammoniacal nitrogen from wastewaters. Therefore, by neglecting the F:M ratio 518 ([NH4]:AOB) ratio, the flask test cannot accurately compare the kinetic parameters of 519 treatment systems treating wastewaters with different NLR. The data reported by Whang 520 et al.(2009) and Kaczorek et Ledakowicz (2006) highlights the limits of the flask test in 
521 defining kinetic parameters for contaminant removal in wastewater biotreatment

522 systems. Reported high nitrification rates at low substrate concentrations and strong 523 inhibition phenomenon at higher substrate concentrations are the results of the 524 inaccurate and variable F:M ratio in flask tests. Therefore, a method that takes microbial 525 population concentration into account when measuring the kinetic parameters for 526 specific substrate (contaminant) removal is deemed necessary to providing accurate 527 data and to comparing treatment systems to each other.

528 In general, reported specific ammonium oxidation rates range from 100 to $225 \mathrm{mg} \mathrm{NH}_{4}-\mathrm{N}$ $529 \mathrm{~L}^{-1} \mathrm{~d}^{-1}$ for effluent concentrations ranging from 200 to $1000 \mathrm{mg} \mathrm{NH}_{4}-\mathrm{N} \mathrm{L}^{-1}$. In this study, 530 measured rates ranged from 115 to $161 \mathrm{mg} \mathrm{NH}_{4}-\mathrm{N} \mathrm{L}^{-1} \mathrm{~d}^{-1}$, which is in accordance with 531 data reported in the literature. Furthermore, since the steady-state was achieved for 532 each measurement, the $\mathrm{F}: \mathrm{M}$ ratio $\left(\mathrm{NH}_{4}: \mathrm{AOB}\right)$ ratio was maintained constant for each 533 measurement; the oxidation rate measured also showed a lower variability over the 534 range of substrate concentration tested.

535 The steady-state approach to measure contaminant removal kinetics addresses all the 536 issues of the flask test method and provides more realistic data. Another option that 537 could be considered to accurately measure those kinetic parameters would be to 538 introduce molecular biology techniques to the flask test method. In this context, real time 539 polymerase chain reaction ( $q P C R$ ) could be used to quantify the proportions of $A O B$ in 540 relation to the total microbial population (Leyva-Díaz, González-Martínez et al. 2015).

541 Then, using the qPCR results, the proper amount of sludge could be added to each flask 542 in order to maintain the F:M ratio constant and representative of the reactor from which it 543 was taken. While this method would be more complex than the steady-state approach, it 544 would be much quicker (days instead of weeks). 


\section{3. Conclusion}

546 The main objectives of this study were to provide an accurate experimental method to

547 measure kinetic parameters in environmental bioprocesses that treat specific

548 contaminants, as well as to fill the gap of information regarding the kinetics parameters

549 for sMBR treating high-strength ammoniacal nitrogen wastewater. The proposed

550 approach consisted in the operation of a lab-scale sMBR with synthetic leachate for 205

551 days with 4 ammoniacal nitrogen concentrations (220, 340, 665 and $\left.1040 \mathrm{mg} \mathrm{NH}_{4}-\mathrm{N} \mathrm{L}^{-1}\right)$

552 until steady-state conditions were reached. At each steady-state, mass balance

553 equations were solved to calculate the specific ammoniacal nitrogen consumption rates.

554 Measured rates ranged from 115 to $161 \mathrm{mg} \mathrm{NH}_{4}-\mathrm{N} \mathrm{L}^{-1} \mathrm{~d}^{-1}$, with the highest rate

555 measured at an effluent concentration of $340 \mathrm{mg} \mathrm{NH}_{4}-\mathrm{N} \mathrm{L}^{-1}$. Experimental data suggest

556 that an inhibition phenomenon occurs at concentrations above $400-500 \mathrm{mg} \mathrm{NH} \mathrm{NH} \mathrm{L}^{-1}$.

557 Therefore, the Haldane model was selected to predict the ammoniacal nitrogen oxidation

558 rates with the following kinetic parameters: $\mathrm{r}_{\mathrm{NH} \text {,max }}=854,4 \mathrm{mg} \mathrm{NH}_{4}-\mathrm{N} \mathrm{L}^{-1} \mathrm{~d}^{-1}, \mathrm{~K}_{\mathrm{S}}=1007$

$559 \mathrm{mg} \mathrm{NH}_{4}-\mathrm{N} \mathrm{L}^{-1}$, and $\mathrm{K}_{\mathrm{I}}=221 \mathrm{mg} \mathrm{NH}_{4}-\mathrm{N} \mathrm{L}^{-1}\left(\mathrm{R}^{2}=0,97\right)$. According to this model, sMBRs

560 that treat high-strength ammoniacal nitrogen are most efficacious when treating effluent

561 with an ammoniacal nitrogen concentration of $472 \mathrm{mg} \mathrm{NH}_{4}-\mathrm{N} \mathrm{L}^{-1}$.

562 The steady-state approach used to measure the kinetic parameters was found to provide

563 more accurate estimation of the kinetic parameters in wastewater biological treatment

564 systems than the conventional flask method. The steady-state approach takes into

565 account the F:M ratio by adapting the mixed liquor to the substrate concentration tested,

566 which is not the case with the flask method. When compared to other ammonia oxidation

567 kinetic studies conducted on high-strength ammoniacal nitrogen wastewaters, results

568 from this study showed both a lower variability in the specific nitrification rates and a 
569 lower effect of the inhibition phenomena. Therefore, this method should be favored for

570 future contaminant removal kinetic studies in wastewater biological treatment systems.

571

\section{Acknowledgements}

573 Support for this study was provided by the NSERC, under a cooperative agreement with

574 the Institut national de la recherche scientifique (INRS), Englobe Corp., and Centre

575 National en Électrochimie et en Technologies Environnementales (CNETE); and by a

576 MITACS doctoral scholarship from MITACS and Englobe Corp. The author would also

577 like to thank Dr. Mohamed Rahni for his advice and manuscript revision, as well as

578 Nathalie Couët for copy editing.

579 
582 Ahmed, F. N. and C. Q. Lan (2012). "Treatment of landfill leachate using membrane 583 bioreactors: A review." Desalination 287: 41-54.

584 Brown, K., A. J. Ghoshdastidar, J. Hanmore, J. Frazee and A. Z. Tong (2013).

585 "Membrane bioreactor technology: A novel approach to the treatment of compost 586 leachate." Waste Management 33(11): 2188-2194.

587 Canziani, R., V. Emondi, M. Garavaglia, F. Malpei, E. Pasinetti and G. Buttiglieri (2006). 588 "Effect of oxygen concentration on biological nitrification and microbial kinetics in a 589 cross-flow membrane bioreactor (MBR) and moving-bed biofilm reactor (MBBR) treating old landfill leachate." Journal of Membrane Science 286(1): 202-212.

Carrera, J., I. Jubany, L. Carvallo, R. Chamy and J. Lafuente (2004). "Kinetic models for nitrification inhibition by ammonium and nitrite in a suspended and an immobilised biomass systems." Process Biochemistry 39(9): 1159-1165.

Dinçer, A. R. and F. Kargı (2000). "Kinetics of sequential nitrification and denitrification processes." Enzyme and microbial technology 27(1-2): 37-42.

Doyle, J., S. Watts, D. Solley and J. Keller (2001). "Exceptionally high-rate nitrification in sequencing batch reactors treating high ammonia landfill leachate." Water Science and Technology 43(3): 315-322.

Dvořák, L., J. Svojitka, J. Wanner and T. Wintgens (2013). "Nitrification performance in a membrane bioreactor treating industrial wastewater." Water Research 47(13): 44124421.

Fogler, H. S. (2006). Elements of Chemical Reaction Engineering, Prentice Hall PTR.

Gagnaire, J., X. Y. Wang, L. Chapon, P. Moulin and B. Marrot (2011). "Kinetic study of compost liquor nitrification." Water Sci Technol 63(5): 868-876.

Hashemi, H. (2015). "Increasing of leachate quality using an integrated aerobic membrane bioreactor." Journal of Advances in Environmental Health Research 3(1).

Hashemi, H., Y. Hajizadeh, M. M. Amin, B. Bina, A. Ebrahimi, A. Khodabakhshi, A. Ebrahimi and H. R. Pourzamani (2016). "Macropollutants removal from compost leachate using membrane separation process." Desalination and Water Treatment 57(16): 7149-7154.

611 He, S.-b., G. Xue and B.-z. Wang (2009). "Factors affecting simultaneous nitrification 612 and de-nitrification (SND) and its kinetics model in membrane bioreactor." Journal of 613 Hazardous Materials 168(2): 704-710.

614 Huang, H., D. Xiao, Q. Zhang and L. Ding (2014). "Removal of ammonia from landfill 615 leachate by struvite precipitation with the use of low-cost phosphate and magnesium sources." Journal of environmental management 145: 191-198.

Kaczorek, K. and S. Ledakowicz (2006). "Kinetics of nitrogen removal from sanitary landfill leachate." Bioprocess and Biosystems Engineering 29(5): 291-304.

Laitinen, N., A. Luonsi and J. Vilen (2006). "Landfill leachate treatment with sequencing batch reactor and membrane bioreactor." Desalination 191(1): 86-91.

Leyva-Díaz, J. C., A. González-Martínez, J. González-López, M. M. Muñío and J. M. Poyatos (2015). "Kinetic modeling and microbiological study of two-step nitrification in a membrane bioreactor and hybrid moving bed biofilm reactor-membrane bioreactor for wastewater treatment." Chemical Engineering Journal 259: 692-702.

Ling, J. and S. Chen (2005). "Impact of organic carbon on nitrification performance of different biofilters." Aquacultural Engineering 33(2): 150-162. 
627 Munz, G., G. Mori, C. Vannini and C. Lubello (2010). "Kinetic parameters and inhibition 628 response of ammonia-and nitrite-oxidizing bacteria in membrane bioreactors and 629 conventional activated sludge processes." Environmental technology 31(14): 1557-1564.

$630 \mathrm{Ng}, \mathrm{A} . \mathrm{N}$. and A. S. Kim (2007). "A mini-review of modeling studies on membrane 631 bioreactor (MBR) treatment for municipal wastewaters." Desalination 212(1-3): 261-281.

632 Roy, D., A. Azaïs, S. Benkaraache, P. Drogui and R. D. Tyagi (2018). "Composting 633 leachate: characterization, treatment, and future perspectives." Reviews in 634 Environmental Science and Bio/Technology 17(2): 323-349.

635 Roy, D., S. Benkaraache, A. Azaïs, P. Drogui and R. D. Tyagi (2019). "Leachate 636 treatment: Assessment of the systemic changes in the composition and biodegradability 637 of leachates originating in an open co-composting facility in Canada." Journal of 638 Environmental Chemical Engineering 7(3): 103056.

639 Whang, L.-M., I.-C. Chien, S.-L. Yuan and Y.-J. Wu (2009). "Nitrifying community 640 structures and nitrification performance of full-scale municipal and swine wastewater 641 treatment plants." Chemosphere 75(2): 234-242.

642 Zolfaghari, M., P. Drogui, S. K. Brar, G. Buelna and R. Dubé (2017). "Unwanted metals 643 and hydrophobic contaminants in bioreactor effluents are associated with the presence 644 of humic substances." Environmental Chemistry Letters 15(3): 489-494.

645 Zuriaga-Agustí, E., J. A. Mendoza-Roca, A. Bes-Piá, J. L. Alonso-Molina, E. Fernández646 Giménez, C. Álvarez-Requena, F. Muñagorri-Mañueco and G. Ortiz-Villalobos (2016).

647 "Comparison between mixed liquors of two side-stream membrane bioreactors treating 648 wastewaters from waste management plants with high and low solids anaerobic 649 digestion." Water Research 100: 517-525. 